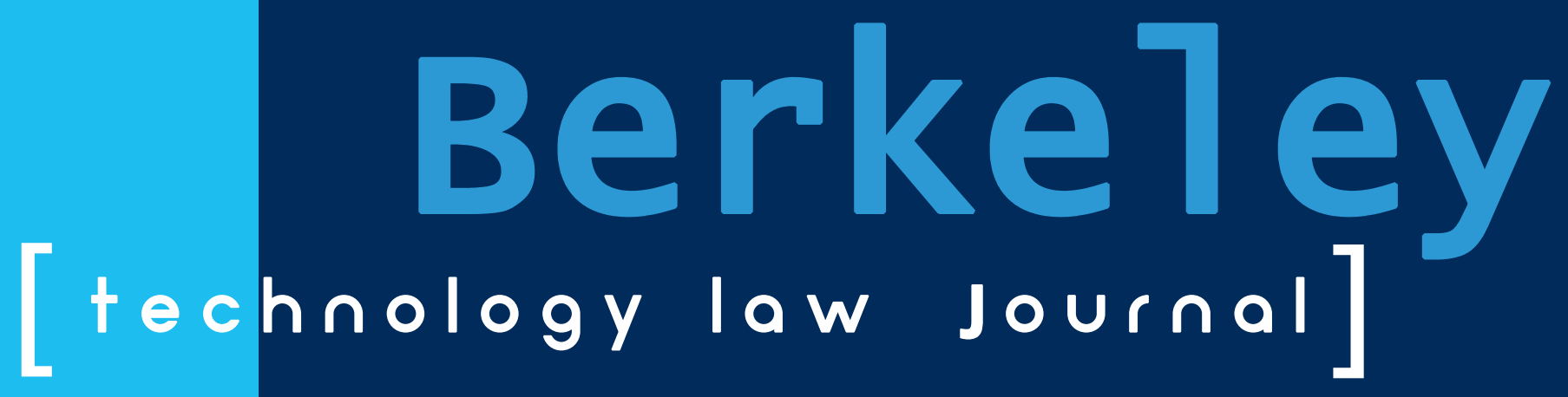

1523 Governance of Intellectual Resources and Disintegration of Intellectual Property in the Digital Age Peter S. Menell

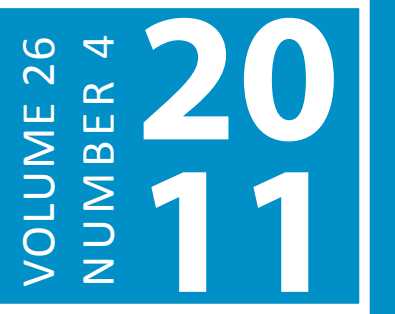

UNIVERSITY OF CALIFORNIA, BERKELEY BOALT HALL 
Production: Produced by members of the Berkeley Technology Law Journal. All editing and layout done using Microsoft Word.

Printer: Joe Christensen, Inc., Lincoln, Nebraska.

Printed in the U.S.A.

Copyright (C) 2011 Regents of the University of California.

All Rights Reserved.

Berkeley Technology Law Journal

University of California

School of Law

3 Boalt Hall

Berkeley, California 94720-7200

btlj@law.berkeley.edu

http://www.btlj.org 


\title{
GOVERNANCE OF INTELLECTUAL RESOURCES AND Disintegration OF INTEllectual Property IN THE Digital AGE
}

\author{
Peter S. Menell
}

\begin{abstract}
The Supreme Court's decision in eBay v. MercExchange brought into focus whether intellectual property policy should follow reflexively in the wake of tangible property doctrines or instead look to the distinctive market failures and institutional features of intellectual resources. Professor Richard Epstein argues in a recent article that "virtually all of the current malaise in dealing with both tangible and intellectual property stems from the failure to keep to the coherent rules of acquisition, exclusion, alienation, regulation, and condemnation that are called for by the classical liberal system ...." Professor Epstein purports to validate what he calls the "carryover hypothesis": that principles governing tangible property "do, and should, influence the growth of intellectual property law," and that apart from durational limits on patents and copyrights, there are essentially no significant departures from the private property mold needed to optimize intellectual property. This Article responds to Professor Epstein's premises, framework, and analysis and provides a broader and richer analytical framework for promoting innovation and creativity in the digital age. In so doing, it demonstrates that intellectual property does not and should not resemble Professor Epstein's idealized classical liberal cathedral. To the contrary, "disintegration" characterizes the intellectual property landscape and hewing to a classical liberal private property paradigm overlooks valuable prescriptions for the evolution of the intellectual property field. While the institution of private property that has developed for tangible resources provides valuable insights into how to encourage efficient economic development, it is not a panacea for all resources, contexts, and societies. Careful consideration of the characteristics of intellectual resources, comparative institutional analysis, and empirical research provide the keys to promoting innovation and creativity.
\end{abstract}

(C) 2012 Peter S. Menell

† Robert L. Bridges Professor of Law, University of California, Berkeley School of Law; Director, Berkeley Center for Law \& Technology. I thank Tom Grey and Mark Lemley for comments on an earlier draft. 


\section{TABLE OF CONTENTS}

I. INTRODUCTION

II. DECONSTRUCTING THE “CLASSICAL LIBERAL" FRAMEWORK.

III. A FUNCTIONAL ANALYSIS OF INTELLECTUAL PROPERTY.

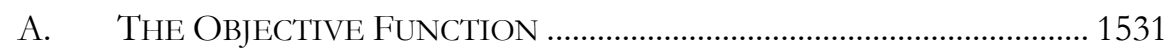

B. PARTICULAR CHARACTERISTICS OF INTELLECTUAL

RESOURCES

C. DiAgNoSIS OF THE “CURRENT MALAISE”....................................... 1538

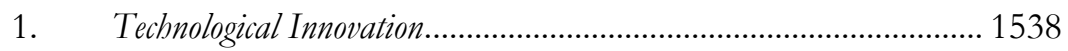

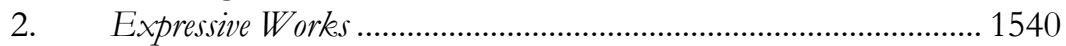

D. COMPARATIVE INSTITUTIONAL ANALYSIS....................................... 1542

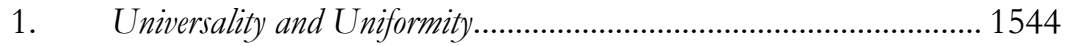

2. The Right To Exclude ………………….................................... 1545

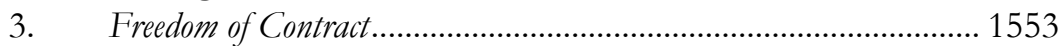

4. Takings and Intellectual Property ……………………………...... 1554

IV. THE DISINTEGRATION OF INTELLECTUAL

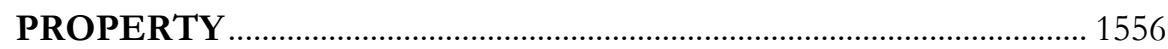

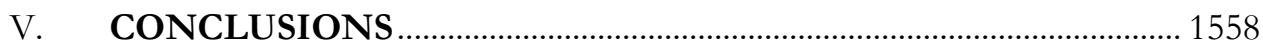

\section{INTRODUCTION}

As technological progress and the digital revolution have reshaped the economic and social landscape, the proper framework for protecting intellectual creativity has become a contentious issue in courts, government agencies, and the halls of Congress, as well as in academic journals. The major titans of industry are no longer General Motors and U.S. Steel, but Google, Apple, Microsoft, and eBay. Their key assets and products are intellectual, not tangible. And they are vulnerable in ways that GM and U.S. Steel never were to having their main business units seriously impaired by the proverbial "patent" needle in the haystack. Strict enforcement of patents in the digital economy, which in many instances resulted from modest investments and never resulted in any business venture, can disrupt established and promising start-up enterprises with little or no advance warning. At the same time, the incentives of pharmaceutical companies, another critical economic sector, depend critically upon patents to recoup investments measured in the hundreds of millions of dollars. Failure to provide strong remedies against infringement of drug patents-which rarely occurs inadvertently - could undermine investment in this vital sector. 
Digital technology is also wreaking havoc in the content industries, where copyrighted works flow without authorization through largely anonymous peer-to-peer networks and "darknets." Aggressive enforcement against filesharers has proven difficult and may well push unauthorized sharing further underground.

In a recent article, The Disintegration of Intellectual Property? A Classical Liberal Response to a Premature Obituary, Professor Richard Epstein offers a deceptively simple prescription: "virtually all of the current malaise in dealing with both tangible and intellectual property stems from the failure to keep to the coherent rules of acquisition, exclusion, alienation, regulation, and condemnation that are called for by the classical liberal system ...." In his article, Professor Epstein purports to validate what he calls the "carryover hypothesis": that principles governing tangible property "do, and should, influence the growth of intellectual property law,"3 and that apart from durational limits on patents and copyrights, there are essentially no significant departures from the private property mold needed for intellectual property.

Beyond the obvious (and not particularly novel) point that private property rules governing tangible property provide a useful analog for thinking about intellectual property regimes, Professor Epstein neither explains nor confronts the "current malaise." After rehashing debates with Professors Thomas Grey and Margaret Radin about the disintegration of "property" law and regulatory takings jurisprudence, Professor Epstein overlooks entirely or breezes by such critical issues as whether patents should be limited to technological advances, the inherent difficulties of defining boundaries in the intellectual domain, the appropriate level of uniformity within patent law, the complexities of promoting cumulative innovation, the

1. Darknets refer to closed file sharing networks. They are sometimes referred to as friend-to-friend networks because they only connect trusted friends. See Darknet (File Sharing), WIKIPEDIA, http://en.wikipedia.org/wiki/Darknet_\%28file_sharing\%29 (last modified Feb. 12, 2012).

2. See Richard A. Epstein, The Disintegration of Intellectual Property? A Classical Liberal Response to a Premature Obituary, 62 STAN. L. REV. 455, 520 (2010) [hereinafter Epstein, Disintegration]. This article plays off of Professor Thomas Grey's seminal article, Thomas C. Grey, The Disintegration of Property, in PROPERTY: NOMOS XXII: YEARBOOK OF THE American Society for Political and Legal Philosophy 69 (J. Roland Pennock \& John W. Chapman eds., 1980), and extends Epstein's earlier claim of "structural unity" between tangible and intellectual property. See also Richard A. Epstein, What Is So Special About Intangible Property? The Case for Intelligent Carryovers (Univ. of Chi. Law \& Econ., Working Paper No. 524, 2010), available at http://papers.ssrn.com/sol3/papers.cfm?abstract_id=1659 999; Richard A. Epstein, The Structural Unity of Real and Intellectual Property, PROGRESS \& FREEDOM FOUND. (Aug. 21, 2006), http://www.pff.org/issues-pubs/pops/pop13.24RAE_ 9_26.pdf.

3. See Epstein, Disintegration, supra note 2, at 480. 
complexities of network effects, and the challenges of enforcing copyrights in the peer-to-peer era so as to focus on such burning questions as the proper interpretation of patent law's exhaustion doctrine.

Professor Epstein purports to adapt the wisdom of tangible property institutions to the attributes of intellectual resources, but then he ignores studies documenting the "current malaise," empirical research on the economic performance of intellectual property systems, and theoretical research on the distinctive economic attributes and market failures associated with modern technology. Like the captain of the Titanic, Professor Epstein is more concerned with rearranging (doctrinal) deck chairs than forthrightly confronting the structural failings of his (private property) vessel in an ocean of (digital) icebergs.

This Article provides a broader and richer analytical framework for promoting innovation and creativity in the digital age. It begins in Part II by deconstructing Professor Epstein's mode of analysis. Part III systematically develops a broad framework for governing intellectual resources based upon their functional characteristics and intellectual property's constitutional purposes. It then debunks the "carryover hypothesis" based on real world, as opposed to idealized, conditions. Part IV then shows that intellectual property does not and should not resemble Professor Epstein's idealized classical liberal cathedral. To the contrary, "disintegration" characterizes the intellectual property landscape and hewing to a classical liberal private property paradigm overlooks valuable prescriptions for the evolution of the intellectual property field.

\section{DECONSTRUCTING THE "CLASSICAL LIBERAL" FRAMEWORK}

Professor Epstein purports to validate his "carryover hypothesis" based principally on four assertions supported by his own analytical intuition:

(1) Since private property is a coherent and well-specified set of rights that works well for tangible property,

(2) The goal is "to determine how few deviations from the traditional views of property in tangibles need to be made in order to develop a sensible system for copyrights and patents."

(3) "The obvious place to start is with the duration of these interests, given that the distinctive feature of information is its capacity to be both shared

4. Id. at 482 . 
and retained at the same time." In Professor Epstein's "preferred system, the scope of pattern coverage should cover the full range of inventions and writing."

(4) After accounting for the durational difference between tangible and intangible property, "it becomes less likely that we can identify any additional functional reasons to reject other pillars of the system of real and personal property dealing with exclusivity, use, and disposition." "7 Beyond the durational issue, Professor Epstein fails to find any significant departures from the private property mold needed for governance of intellectual property.

Whether or not Professor Epstein's analysis achieves “classical liberal values," it falls well short of comprehending, much less addressing, the constitutional purposes underlying intellectual property protection: promoting progress in technology and expressive creativity while preserving freedom of expression. Professor Epstein's analysis utterly fails to capture the differences between intellectual property and tangible property. For Step 1 of his analysis, he replows old debates with Professor Thomas Grey about the disintegration of the property system and with Professor Margaret Radin about regulatory takings. He rejects Grey's contention that the fragmentation and manipulation of property interests in advanced capitalist economies has undermined romantic, classical liberal notions of private property. ${ }^{9}$ Professor Epstein then critiques Radin's notion of "conceptual severance": the idea that intangible rights can and should be understood differently than tangible resources. ${ }^{10}$

5. Id.

6. Id. at 484 .

7. Id. at 483 .

8. Many libertarians have serious reservations about extrapolating property rights in tangible resources to the realm of intangibles. See, e.g., F.A. HAYEK, THE FATAL CONCEIT: THE ERrors of SOCIALISM 36 (W.W. Bartley III ed., 1988) (observing, in commenting on patents and copyrights, that "it is not obvious that such forced scarcity is the most effective way to stimulate the human creative process"); SAM WiLLIAMS, FrEE AS IN FrEEDOM: Richard Stallman's Crusade for Free Software (2002); N. Stephan Kinsella, Against Intellectual Property, 15 J. LiberTARiAn STUD. 1, 27-28 (2001); Roderick T. Long, The Libertarian Case Against Intellectual Property Rights, 3 Formulations, no. 1, Autumn 1995, available at http://freenation.org/a/f3111.html; Tom G. Palmer, Are Patents and Copyrights Morally Justified? The Philosophy of Property Rights and Ideal Objects, 13 HARV. J.L. \& PUB. POL'Y 817 (1990); Tom G. Palmer, Intellectual Property: A Non-Posnerian Law and Economics Approach, 12 Hamline L. Rev. 261 (1989); Jesse Walker, Copy Catfight: How Intellectual Property Laws Stifle Popular Culture, REASON (Mar. 2000), http://www.reason.com/news/show/27635.html.

9. Epstein, Disintegration, supra note 2, at 462-72 (discussing Grey, supra note 2).

10. Id. at 472-80 (discussing Margaret Jane Radin, The Liberal Conception of Property: Cross Currents in the Jurisprudence of Takings, 88 COLUM. L. REV. 1667 (1988)). 
Professor Epstein's carryover hypothesis builds on this foundation. But if private property rights for tangible things have eroded, then the starting point for his analysis is that much weaker. If nothing else, voluminous scholarship during the past several decades has shown that institutions other than private property are capable of achieving productive resource use (and other social aims). ${ }^{11}$ Nonetheless, Professor Epstein sees classical liberal private property for tangible resources as the only possible foundation for governing intellectual resources.

Professor Epstein is evasive on what he actually means by the classical liberal private property system for tangibles. When fending off critiques, he cautions against falling into the Blackstone trap: reading too literally Blackstone's famous definition of property as "that sole and despotic dominion which one man claims and exercises over the external things of the world, in total exclusion of the right of any other individual in the universe." ${ }^{\prime 2}$ At times, Professor Epstein waxes about the ways in which traditional property rights systems have been adapted for water resources, ${ }^{13}$ celebrating the shift from riparian rights systems in rainy regions to the use of prior appropriation in the more arid West. ${ }^{14}$ But when he is arguing to the

11. See John P. Dwyer \& Peter S. Menell, Property Law and Policy: A Comparative institutional Perspective (1998); Neil K. Komesar, Imperfect Alternatives: Choosing Institutions in Law, Economics, and Public Policy (1994); ELINOR OSTROM, UNDERSTANDING INSTITUTIONAL DiVERSITY (2005); ELINOR Ostrom, Governing the Commons: The Evolution OF Institutions for Collective Action (1990); Steven Weber, The Success of Open Source (2004).

12. 2 William Blackstone, Commentaries on the Laws of ENGLAND 2 (1775).

13. See Richard A. Epstein, The Property Rights Movement and Intellectual Property: A Response to Peter Menell, Regulation, Winter 2008, at 58, 59.

14. Justice Cardozo captures the shift eloquently:

Sooner or later, if the demands of social utility are sufficiently urgent, if the operation of an existing rule is sufficiently productive of hardship or inconvenience, utility will tend to triumph.... We have a conspicuous illustration in the law of waters in our western states. "Two systems of water law are in force within the United States - the riparian and the appropriation systems." The system first named prevails in thirty-one of the forty-eight states. Its fundamental principle is "that each riparian proprietor has an equal right to make a reasonable use of the waters of the stream, subject to the equal right of the other riparian proprietors likewise to make a reasonable use." Some of the arid states of the west found this system unsuited to their needs. Division of the water "into small quantities among the various water users and on the general principle of equality of right" would be a division "so minute as not to be of advantage to anybody." "It is better in such a region that some have enough and others go without, than that the division should be so minute as to be of no real economic value." The appropriation system built upon the recognition of this truth. Its fundamental principle is "that the water user 
Supreme Court that injunctions should be automatically granted in intellectual property cases by analogy to real property law, his conception of the private property system comes dangerously close to the Blackstone trap. ${ }^{15}$ In his present article, he defends "the soundness [and] adequacy of the classical liberal conception of property rights embodied in Blackstone's famous definition." "16 If not over the edge, Professor Epstein rests at the rim of the Blackstone trap, allowing modest leeway only for compelling necessity, eminent domain (with a strict public use requirement), and laches and estoppel.

Professor Epstein's Step 2 is where the first rabbit goes into the hat. If you anchor your framework in a particular mode of governance, there is a good chance that you will conclude that that mode of governance should apply. That is especially true if you do not systematically characterize the resources at issue or catalog the range of market failures that might lead you to other modes of governance. Part III of this Article delves more deeply into the details. Thus, the principal pillars on which Professor Epstein builds his edifice are illusory. He refuses to characterize the contours of the classical liberal theory. Secondly, he assumes tautologically that the classical liberal theory is best and therefore society need only determine "bow few deviations from the traditional views of property in tangibles need to be made in order to develop a sensible system for copyrights and patents." ${ }^{, 17}$

In Step 3 Professor Epstein acknowledges that information differs from tangible resources in that it is non-rivalrous-i.e., one person's use of

who first puts to beneficial use-_irrigation, mining, manufacturing, power, household, or other economic use-the water of a stream, acquires thereby the first right to the water, to the extent reasonably necessary to his use, and that he who is the second to put the water of the stream to beneficial use, acquires the second right, a third to put it to use acquires the third right, a right subordinate to the other two, and so on throughout the entire series of uses." Here we have the conscious departure from a known rule, and the deliberate adoption of a new one, in obedience to the promptings of a social need so obvious and so insistent as to overrun the ancient channel and cut a new one for itself.

Benjamin N. Cardozo, The Growth of the Law 117-20 (1924) (citations omitted). Unlike Epstein, Justice Cardozo bases this evolution not on the superiority of classical property but rather on a functional, utilitarian framework. Epstein is too focused on shoehorning resource governance into his classical liberal theory to offer a general theory.

15. See Brief of Various Law \& Economics Professors as Amici Curiae in Support of Respondent, eBay Inc. v. MercExchange, L.L.C., 547 U.S. 388 (2006) (No. 05-130), 2006 WL 639164 [hereinafter Epstein eBay Brief].

16. See Epstein, Disintegration, supra note 2, at 461.

17. See id. at 482 . 
information does not limit another's use. ${ }^{18}$ Consequently, it makes sense to limit intellectual property duration. There are other ways of dealing with the non-rivalrous characteristic, as I explore in Part III, but Professor Epstein does not want to explore inroads into such areas as exclusion rights, so duration is the answer. Professor Epstein provides no analysis of why duration is the best or only tool to deal with non-rivalry. Duration is an important tool, but it should not be the only one considered. Moreover, Professor Epstein entirely overlooks the cumulative innovation ${ }^{19}$ aspect of information, which most intellectual property scholars consider to be a critical rationale for limiting the time and strength of intellectual property rights. ${ }^{20}$

Professor Epstein continues to oversimplify matters by proclaiming that copyright should be longer than patent protection and that all forms of invention and expressive creativity should be protected through intellectual property-referencing the famous and famously mischaracterized "anything under the sun" language from the legislative history of the 1952 Patent Act. ${ }^{21}$ Putting intellectual resources as heterogeneous as pharmaceutical advances and business methods in a largely uniform patent system, and putting photographs and novels in a largely uniform copyright system, generates

18. See id. at 483 ("But the social gains from the expiration of the copyright or invention are large because that expiration allows an extensive nonrivalrous use ....”). Yet in the introduction to his article, Professor Epstein discounts the many modern writers who emphasize this very characteristic in advocating a sui generis approach to intellectual property. See id. at 458 ("Their claim of separation is overstated.").

19. Cumulative innovation refers to the fact that most innovation builds upon prior advances. Therefore, intellectual property systems must pay careful attention to balancing incentives between pioneers and those who improve upon prior advances.

20. See Peter S. Menell \& Suzanne Scotchmer, Intellectual Property Law, in 2 HANDBOOK OF LAW AND ECONOMICS 1473, 1476-78, 1499-1511 (A. Mitchell Polinsky \& Steven Shavell eds., 2008).

21. That phrase first surfaced in patentable subject matter jurisprudence in Application of Bergy, 596 F.2d 952, 961 (C.C.P.A. 1979). It was then picked up in Diamond v. Chakrabarty, 447 U.S. 303, 309 (1980), and Diamond v. Diehr, 450 U.S. 175, 182 (1981), without its full context or even ellipses. It was then mischaracterized in State Street Bank \& Trust Co. v. Signature Financial Group, 149 F.3d 1368 (Fed. Cir. 1998), cert. denied, 525 U.S. 1093 (1999). See In re Bilski, 545 F.3d 943, 966-98 (Fed. Cir. 2008) (en banc) (Dyk, J. \& Linn, J., concurring) (agreeing "with Judge Mayer that, when read in context, the statement undercuts the notion that Congress intended to expand the scope of $\int 101$ "); $i d$. at 1000 (Mayer, J., dissenting) ("This statement does not support the contention that Congress intended 'anything under the sun' to be patentable. To the contrary, the language supports the opposite view: a person may have 'invented' anything under the sun, but it is 'not necessarily patentable' unless the statutory requirements for patentability have been satisfied."); see also Brief Amici Curiae of Professors Peter S. Menell \& Michael J. Meurer in Support of Respondent, Bilski v. Kappos, 130 S. Ct. 3218 (2009) (No. 08-964), 2009 WL 3199629 (providing comprehensive analysis of the legislative history of the 1952 Patent Act). 
tremendous problems of over- and under-protection. Yet Professor Epstein sees one-size-fits-all for inventions and one-size-fits-all for expressive works to be the optimum. As explored in Section III.C.1, Professor Epstein fails to address all of the characteristics that distinguish intellectual from tangible resources and ignores the alternative institutional and design options.

Unlike Step 2, where we can see the rabbit going into the hat, Professor Epstein's conclusion in Step 4-that duration is effectively the only difference between tangible and intellectual property-is pure magic. When the only tool that you have in your box is a hammer, every problem looks like a nail. When that tool is classical liberal "property rights," then all of its features (except the constitutionally-mandated "limited terms" constraint) "carry over" to intellectual property. By glossing over the complexities of intellectual resources, Professor Epstein short-circuits even his own analytical framework.

\section{A FUNCTIONAL ANALYSIS OF INTELLECTUAL PROPERTY}

In contrast to Professor Epstein's framework, this Part develops a functional analysis of the governance of intellectual resources based on first principles. The appropriate place to start is with the goals for the analytical framework. Section B characterizes the resources at issue. Section C diagnoses the "current malaise" affecting technological innovation and expressive creativity. Section D frames comparative institutional analysis of some of the key challenges.

\section{A. The Objective Function}

Contrary to Professor Epstein's premise, the goal of intellectual property law and policy in the United States is not confined to promoting liberty with a utilitarian gloss. Rather, the Intellectual Property Clause of the U.S. Constitution empowers Congress " $[\mathrm{t}]$ o promote the Progress of Science and useful Arts, by securing for limited Times to Authors and Inventors the exclusive Right to their respective Writings and Discoveries."22 This Clause

22. U.S. CONST., art. I, $\int 8$, cl. 8. As the Supreme Court has noted:

"The copyright law, like the patent statutes, makes reward to the owner a secondary consideration." United States v. Paramount Pictures, 334 U.S. 131,158 . However, it is "intended definitely to grant valuable, enforceable rights to authors, publishers, etc., without burdensome requirements: 'to afford greater encouragement to the production of literary [or artistic] works of lasting benefit to the world.' "' 
interacts with the First Amendment's guarantee of freedom of speech. Liberty may be a means to these ends, but it is not the only means.

Professor Epstein's premise would take on greater moment if the Supreme Court interpreted the "exclusive right" element of the Intellectual Property Clause to constrain Congress in enacting intellectual property laws to a classical liberal notion of property. But such an interpretation conflicts with the language of the Clause, the limited times caveat, and centuries of jurisprudence. Congress has relatively broad leeway in enacting intellectual property law ${ }^{23}$ and is not constrained to even a narrowly utilitarian objective in crafting intellectual property law. ${ }^{24}$

Throughout its history, the Copyright Act has promoted preservation, dissemination, and distributive justice through deposit and various access exemptions. ${ }^{25}$ The Copyright Act of 1976 seeks to address the problem of unremunerative transfers in author-publisher relationships by affording authors (and their statutory successors) an inalienable right to reclaim copyright thirty-five years after execution of the transfer. ${ }^{26}$ Such provisions directly contradict the classical liberty framework by limiting freedom of contract. Professor Epstein might not like this policy-after all, it complicates business transactions ${ }^{27}$ and causes substantial confusion in the courts $^{28}$ - but he cannot seriously contend that copyright's termination regime does not "disintegrate" the classical liberal cathedral to some degree. Copyright's various features such as compulsory licensing and exemptions further erode the cathedral.

Wash. Pub. Co. v. Pearson, 306 U.S. 30 (1939). The economic philosophy behind the clause empowering Congress to grant patents and copyrights is the conviction that it is the best way to advance public welfare through the talents of authors and inventors in "Science and useful Arts." Sacrificial days devoted to such creative activities deserve rewards commensurate with the services rendered. Mazer v. Stein, 347 U.S. 201, 219 (1954).

23. See Eldred v. Ashcroft, 537 U.S. 186 (2003).

24. See Golan v. Holder, 132 S. Ct. 873, 888 (2012) (observing that "[n]othing in the text of the Copyright Clause confines the 'Progress of Science' exclusively to 'incentives for creation" " (citation omitted)).

25. See Peter S. Menell, Knowledge Accessibility and Preservation Policy for the Digital Age, 44 Hous. L. REV. 1013 (2007).

26. See 17 U.S.C. \ 203 (2006); see also id. \ 304(c), (d) (56- and 75-year terminations for pre-1978 works).

27. See Lauren A.E. Schuker, Heirs of Comic Book Creator Seek To Recapture Copyrights, WALL ST. J., Sept. 21, 2009, at B7 (reporting that heirs of comic book creator Stan Kirby are seeking to reclaim copyrights to the Marvel super heroes, casting a cloud of uncertainty over Disney's \$4 billion acquisition of Marvel's characters).

28. See Peter S. Menell \& David Nimmer, Poob-Poobing Copyright Law's "Inalienable" Termination Rights, 57 COPYRIGHT SOC'Y 799 (2010). 
Thus, the classical liberal framework lacks constitutional, legislative, and jurisprudential support as "the" objective for intellectual property law and policy.

\section{B. Particular Characteristics of Intellectual Resources}

The principles that make tangible property rights economically efficient do not always apply to intellectual property ${ }^{29}$ - a reality that appears lost on Professor Epstein. The utilitarian basis for protecting tangible resources through the institution of private property rests on a sound theoretical and empirical foundation. The biologist Garrett Hardin offered the now classic parable of the "tragedy of the commons," which highlights the potential for overuse of resources that are not subject to exclusion. ${ }^{30}$ The economist Harold Demsetz posited that exclusive private property systems emerge as externalities become more prevalent and the costs of enforcing private property decline. ${ }^{31}$ Using a simple model of land cultivation, law and economics scholar (and Judge) Richard Posner posited three criteria for an efficient allocation of land resources: (1) universality - that all land is owned, (2) exclusivity, and (3) transferability. ${ }^{32}$ Private property directly addresses the problems of scarcity, rivalry, and depletion—one person's use and enjoyment of the resource diminishes the use and enjoyment by others. Exclusivity affords the owner the opportunity to develop the resource without risk of expropriation. In general, private property succeeds in promoting efficient resource development when boundaries and rights are clearly delineated and enforcement is inexpensive and effective. A robust body of historical and empirical research suggests that the institution of private property supports economic development. ${ }^{33}$

29. Peter S. Menell \& Michael Meurer, Notice Failure and Notice Externalities (Boston Univ. Sch. of Law, Law and Economics Research Paper No. 11-58, 2011), available at http:/ / papers.ssrn.com/sol3/papers.cfm?abstract_id=1973171.

30. See Garrett Hardin, The Tragedy of the Commons, 162 SCIENCE 1243 (1968).

31. See Harold Demsetz, Toward a Theory of Property Rights, 57 ECON. REV. 347 (1967).

32. Richard A. Posner, ECONOMiC ANALYsis OF LAw 33 (6th ed. 2003).

33. See Philip Keefer \& Stephen Knack, Why Don't Poor Countries Catch Up? A CrossNational Test of an Institutional Explanation, 35 ECON. INQUIRY 590 (1997) (finding that contract enforceability, risk of government expropriation, rule of law, and other proxies for the quality of property rights are strongly and positively correlated with national economic growth); see also Douglass C. NORTH, STRUCTURE AND CHANGE IN ECONOMIC HisTORY 149-52, 166-67 (1981) (finding that secure property rights facilitated the British Industrial Revolution; by contrast, undocumented and disputed feudal customary rights impeded economic growth in many European nations); Philip Keefer \& Stephen Knack, Institutions and Economic Performance: Cross-Country Tests Using Alternative Institutional Measures, 7 ECON. \& POL. 207, 219-20 (1995) (finding that "secure property rights encourage fixed investments"). 
However, development of intellectual resources differs fundamentally from the development of tangible resources. ${ }^{34}$ Therefore, it cannot be assumed that intellectual resources should be governed by the same rules that have developed for tangible resources-even with the duration adjustment. And the historical and empirical evidence regarding patents bears this out. In a broad survey of studies, Professors James Bessen and Michael Meurer find that:

The historical evidence, the cross-country evidence, and the evidence from economic experiments all point to a marked difference between the economic importance of general property rights and the economic importance of patents or intellectual property rights more generally. With the cross-country studies in particular, the quality of general property rights institutions has a substantial direct effect on economic growth. Using the same methodology and in the same studies, intellectual property rights have at best only a weak and indirect effect on economic growth.... [T]he empirical evidence strongly rejects simplistic arguments that patents universally spur innovation and economic growth. "Property" is not a ritual incantation that blesses the anointed with the fruits of innovation; legislation of "stronger" patent rights does not automatically mean greater innovation. Instead, the effectiveness of patents as a form of property depends critically on the institutions that implement present law. And there appear to be important differences in the effectiveness of implementation across different technologies and industries. ${ }^{35}$

By their inherent nature, intellectual resources are neither rivalrous nor depletable. We can all enjoy knowledge simultaneously without diminution. Hence scarcity is not the problem. The principal economic justification for intellectual property derives from the inability of a competitive market to support an efficient level of creativity-particularly where creativity is costly, easily perceived, and relatively inexpensive to imitate. A competitive market will drive profits to zero, not accounting for sunk costs such as research and development. Although imitation keeps prices low for consumers and avoids deadweight loss of monopolistic exploitation, it produces a sub-optimal level of investment in creativity. Most creators or enterprises would not invest in innovation if rivals could enter the market and dissipate the profit before research and development costs adjusted for attendant risks could be recovered.

34. See generally Menell \& Scotchmer, supra note 20, at 1475-83.

35. See James Bessen \& Michael J. Meurer, Patent Failure: How Judges, BUREAUCRATS, AND LAWYERS PUT INNOVATORS AT RISK 92-93 (2008). 
A second problem relates to the cumulative nature of innovationwhereby first-generation inventions become inputs for second-generation innovators. To reward first generation innovators sufficiently for inventions that may produce positive spillovers - enabling second-generation inventions such as improvements, new applications, and accessories-first-generation innovators should be able to appropriate some of the value of secondgeneration innovations. On the other hand, providing even a share of the second-generation innovators' returns to the first-generation innovator reduces the incentive for second-generation innovators to pursue their research.

Intellectual property law attempts to solve these problems by granting time-limited rights to creators of knowledge. In essence, intellectual property law creates artificial scarcity so as to stimulate a market for what would otherwise be a non-rivalrous and non-excludable good. Such control, however, reduces social welfare through the deadweight loss resulting from monopoly exploitation and inhibits cumulative innovation. ${ }^{36}$ Ideally, society could avoid or lessen these effects while generating adequate incentives for innovation. Whereas intellectual property's inherent nature allows for sharing that enhances the enjoyment of others at the cost of disincentivizing future creativity, no comparable challenges exist in the realm of tangible resources. Allowing more people onto a given piece of land or more people to share an ice cream cone diminishes the enjoyment of others.

Thus, by adhering to a strict construction of his carryover hypothesis, Professor Epstein overlooks several other important considerations in the governance of intellectual resources that do not arise for tangible resources. For instance, the incentive problems that might justify intellectual property protection can be addressed in whole or part through alternative modes of appropriability. Where these other mechanisms operate effectively, the optimal policy is to disseminate knowledge freely and without restriction. In many fields of technological innovation, the government directly funds research and development. Moreover, indirect modes of appropriabilitysuch as advertising-can address the incentive problems in some markets. Commercial broadcasting, for example, has been "free" to consumers for much of its existence due to the technological characteristics of this medium, yet broadcasters have developed profitable business models that sponsor creation of the content. Furthermore, intellectual property regimes overlap in ways that address appropriability problems. Thus, computer software derives

36. Licensing can correct for the latter difficulty, but only if search and negotiation costs are manageable. 
substantial protection from trade secrecy and copyright protection, even though these regimes do not directly protect the functional characteristics of the products. Such protection can obviate or substantially substitute for patent protection for computer software, which can have various undesirable effects. ${ }^{37}$

The computer software marketplace raises a distinctive concern that has no clear analog in tangible resource markets: the problem of network externalities. The value that one person derives from a good can be related to how many other people use that same platform. Such effects can be direct (e.g., telecommunications networks-where the value to each user depends directly on the number of other users on that network) as well as indirect (e.g., interoperable software products-where the value of a hardware product depends on the amount and quality of the software available to run on that platform, which in turn depends on the number of users of the hardware product). Achieving the proper balance of incentives in network markets requires great care and often places intellectual property protection in tension with antitrust law. ${ }^{38}$

The interoperability concern has called attention to the advantages of collaborative, non-proprietary innovation systems. Developers of open source software-who eschew proprietary business models-have emerged as a powerful force in internet software markets precisely because it is nonexclusionary. ${ }^{39}$

Moving beyond these important functional differences between tangible and intangible resource markets, the essential conditions for tangible property to function effectively-low cost administration, clearly delineated boundaries, and inexpensive enforcement-should not be assumed to operate in intellectual property systems. Real property institutions typically work so smoothly that administrative, search, and enforcement costs rarely affect resource development. The physical nature of the tangible resources, combined with the observability of possession, make for a transparent, reliable, and inexpensive system of demarcation and clearance. Land recording systems enable quick and reliable search of deed registries. The legal description of real property deeds ensures that land surveyors can inexpensively and precisely determine boundaries. Even prescriptive uses are usually readily observable.

37. Peter S. Menell, Tailoring Legal Protection for Computer Software, 39 STAN. L. REV. 1329 (1987).

38. See id. at 1366.

39. See Robert P. Merges, $A$ New Dynamism in the Public Domain, 71 U. CHI. L. REV. 183, 191-93 (2004). 
By contrast, the direct and indirect administrative, search, and enforcement costs of intellectual property systems are substantial. Applying for a patent is costly and time consuming. Whereas real property grants are judged against a readily searchable and exhaustive index and a simple, objective priority rule, patents are evaluated against a vast reservoir of knowledge that can be difficult to collect and an inherently indeterminate non-obviousness standard. Limitations on the Patent Office's time and resources inevitably result in prior art being overlooked and patents of questionable validity being granted. Furthermore, the boundaries of intellectual property rights can be difficult to ascertain. The intangible nature of intellectual property means that boundaries are defined by words as opposed to quantitative, geophysical measurements. The resulting disputes over claim interpretation play a central role in most patent infringement lawsuits. $^{40}$

The costs of ascertaining patent boundaries reverberate throughout the technology sector. Unlike tangible property systems, the proliferation of patent claims, relatively low reliability of patent grants, fuzzy boundaries surrounding the claims, and substantial costs of resolving disputes impose a high barrier on innovators and prospective investors.

For these reasons, empirical evidence on the economic effects of patent protection is mixed, in contrast with research on the efficacy of tangible property rights. ${ }^{41}$ Historical research on the industrial revolution indicates that nations without patent systems were just as innovative as those that had such systems. ${ }^{42}$ Cross-national time-series studies since that era show a strong correlation between property rights and economic growth, but much weaker evidence with respect to patents. ${ }^{43}$ The most that can be discerned about patents is that they are correlated with research and development spending in developed nations, although the causality is unclear. ${ }^{44}$ Studies of the effects of legal change are also inconclusive. ${ }^{45}$ Whereas Soviet-bloc nations that developed strong property and market institutions following the dissolution of the Soviet Union ultimately experienced strong economic growth (after an initial period of sharp decline), nations that have strengthened their patent rights do not show clear evidence of increased innovation except to a limited

40. See Peter S. Menell, Matthew D. Powers \& Steven Carlson, Patent Claim Construction: A Modern Synthesis and Structured Framework, 25 BERKELEY TECH. L.J. 711 (2010).

41. See BESSEN \& MEURER, supra note 35, at 92-93.

42. See id. at 80 .

43. See id. at 83-84.

44. See id. at 83 .

45. See id. at 85 . 
degree in the wealthiest nations. ${ }^{46}$ Survey evidence and case studies show that patent protection plays a critical role in promoting research and development investment in the pharmaceutical and chemical industries, but it is much less significant-compared to lead-time and trade secrecy-in most other industries. ${ }^{47}$ As the next Section explores, the evidence on the effects of patent protection has turned even more sour for the digital technology sector during the past decade.

The copyright system avoids the up-front costs of the patent system by not requiring examination and making registration optional. But there can be difficult problems after the fact. Hollywood lawyers are familiar with the phrase "where there's a hit, there's a writ." Popular films and sound recordings frequently generate copyright litigation where experts disagree about the extent to which a work is protectable and infringed. The jury system and the subjectivity of the infringement standard-which asks whether the allegedly infringing work is "substantially similar" to the protected expression — create considerable uncertainty.

For most of the twentieth century, the costs of enforcing copyright protection were relatively manageable. Those operating pirate printing presses and record factories could not easily get their wares into mainstream markets without detection. And proving infringement in piracy cases was quite easy. But as the next Section discusses, the digital age has turned copyright enforcement on its head.

\section{Diagnosis of the "Current Malaise”}

Professor Epstein asserts that his carryover prescription addresses "virtually all of the current malaise in dealing with . . intellectual property.",48 Yet he offers no account of the "current malaise" other than criticism of the Supreme Court's eBay decision and various other decisions that do not follow his classical liberal property rights ideal. Rather than follow such circular reasoning, this Section offers a more objective diagnosis.

\section{Technological Innovation}

The malaise plaguing the patent system can be traced principally to the proliferation of software and business method patents beginning in the mid 1990 s. $^{49}$ The software industry developed in the 1960s, 1970s, and 1980s

46. See id. at $83-84$.

47. See id. at 89 .

48. Epstein, Disintegration, supra note 2, at 520.

49. See generally BesSEn \& Meurer, supra note 35; DAN L. BurK \& MArK A. LemLey, The Patent Crisis and How the Courts Can Solve It (2009); Adam B. JafFe \& Josh LeRner, InNOVAtion and Its Discontents (2004); A PATENT System FOR the 21st 
without any significant role for patent protection. The major vendors-from Microsoft to Oracle-were able to protect software products adequately through contract, trade secrecy, and copyright protection, as well as through technological measures (encryption) and business strategies (versioning). These protections and strategies deterred piracy, provided adequate lead time, and supported vibrant competition. Through much of this period, the standards for patentable subject matter ${ }^{50}$ kept patent protection for software at the periphery of the industry.

This changed dramatically beginning in the mid 1990s. The U.S. Court of Appeals for the Federal Circuit relaxed the patentable subject matter limitations, particularly relating to software and business methods. ${ }^{51}$ With the State Street Bank decision in 1998, the Federal Circuit largely eliminated the subject matter requirement. ${ }^{52}$ At the same time, the emergence of the Internet as a commercial platform, along with great advances in the computing power and storage capacity of microcomputers, fueled the dot-com boom. These factors produced a flood of software patent applications. The Patent Office has since struggled to keep up with the workload and provide quality examination. Even as staffing has improved, the difficulty of finding prior art-which can range from prior patents and technical journal publications to products and know-how in the industrycontinues to raise concerns about the quality of software patent examination.

According to the recent, comprehensive empirical study by Professors James Bessen and Michael Meurer, the performance of the U.S. patent system deteriorated markedly beginning in the mid 1990s as patent litigation costs soared. ${ }^{53} \mathrm{By}$ the end of that decade, the cost of patent litigation for public firms outside of the chemical and pharmaceutical industries exceeded the profits derived from patents. $^{54}$ The problems have been most pronounced in the software and business method marketplaces, where patents are functioning more as a tax on research and development than as an innovation incentive. Non-practicing entities have become a major source

Century (Stephen A. Merrill et al. eds., 2004); U.S. Fed. Trade Comm’N (FTC), To Promote Innovation: The Proper Balance of Competition and Patent Law and POLICY (2003). (1981).

50. See Gottschalk v. Benson, 409 U.S. 63 (1972); Diamond v. Diehr, 450 U.S. 175

51. See State St. Bank \& Trust Co. v. Signature Fin. Grp., 149 F.3d 1368 (Fed. Cir. 1998), cert. denied, 525 U.S. 1093 (1999); In re Alappat, 33 F.3d 1526 (Fed. Cir. 1994); see also U.S. Patent \& Trademark Office, Examination Guidelines for Computer-Related Inventions, 61 Fed. Reg. 7478 (Feb. 28, 1996).

52. See State Street Bank, 149 F.3d at 1375-77.

53. See BESSEN \& MEURER, supra note 35, at 144.

54. See id. at 138-42. 
of patent litigation in the software and internet industries. ${ }^{55}$ Among established entities, an arms race has taken hold whereby firms expend tremendous resources on patent acquisition and maintenance strategies driven more by defensive concerns than real innovation. ${ }^{56}$ In the software industry, patents function more as insurance and bargaining chips than as fuel for investment.

The cause of the patent crisis derives principally from the inherently ambiguous nature of software patent claims, the difficulty of evaluating software patent applications, ${ }^{57}$ and the cost for industry players to wade through the veritable deluge of software and business method patents ${ }^{58}$ to determine intellectual property boundaries. ${ }^{59}$ These factors introduce tremendous litigation risk for start-ups and established companies alike. Companies in these industries face a problem much like the Hollywood lawyer-where there's a digital product or service "hit," there are usually multiple "writs" - often in the Eastern District of Texas. ${ }^{60}$ Even before a hit, inventors and investors incur substantial direct and indirect costs to deal with the uncertainties of an ambiguous intellectual property landscape.

\section{Expressive Works}

The malaise plaguing the copyright system can be traced to another ramification of the digital revolution: the emergence of largely anonymous peer-to-peer networks. ${ }^{61}$ This technology, made famous by Napster, enables anyone with an internet connection to distribute copyrighted works - their own or those of others-to everyone else on the Internet. This has resulted in rampant unauthorized distribution of sound recordings and other forms of digital media. From the early 1970s through 1999, the year Napster appeared, the sale of sound recordings per capita in the United States more than doubled. ${ }^{62}$ In the decade since, record sales have dropped to pre-1970 levels.

55. See John R. Allison, Mark A. Lemley \& Joshua Walker, Extreme Value or Trolls on Top? The Characteristics of the Most-Litigated Patents, 158 U. PA. L. REV. 1, 31-33 (2009) (finding that between 2000 and 2007, non-practicing entities brought $16 \%$ of the once-litigated patents and over $80 \%$ of the suits filed involving the most-litigated patents).

56. See FTC, supra note 49, at 3-33 (describing the use of defensive patenting).

57. See Mark A. Lemley, Rational Ignorance at the Patent Office, 95 Nw. U. L. REV. 1495, 1500 (2001).

58. See BESSEN \& MEURER, supra note 35, at 122, 128-29, 153, 193.

59. See Mark A. Lemley, Ignoring Patents, 2008 MiCH. ST. L. REV. 19.

60. See Jeanne C. Fromer, Patentography, 85 N.Y.U. L. REV. 1444 (2010).

61. See Epstein, Disintegration, supra note 2, at 503-07 (discussing UMG Recordings, Inc. v. Augusto, 558 F. Supp. 2d 1055 (C.D. Cal. 2008)).

62. See Stanley J. Liebowitz, File-Sharing: Creative Destruction or Just Plain Destruction?, 49 J.L. \& ECON. 1, 14 (2006). 
The principal explanation is the availability of sound recordings through unauthorized channels. ${ }^{63}$ Such unauthorized distribution is growing in other important content markets, such as motion pictures and television programming. Books and other literary content may not be far behind as reader technologies (such as Amazon's Kindle and Apple's iPad) become more diffused. ${ }^{64}$

Under these conditions, the copyright system cannot function as an effective governance institution. Creators cannot derive a return for their works commensurate with how they are valued in the marketplace. Intermediaries distort content they run-e.g., by integrating advertisingwhich makes it harder for consumers to express their preferences to the market. ${ }^{65}$ Ultimately, creators and consumers suffer from the inability of markets to communicate value. Professor Epstein's failure to perceive this problem suggests that his analysis is driven by an agenda other than promoting progress in the creative arts. If one were to judge from Professor Epstein's article, the "current malaise" plaguing the copyright system stems from a lower court decision interpreting the first sale doctrine broadly. ${ }^{66}$ Professor Epstein makes passing reference to his "ferocious" opposition to adding twenty years to the copyright term ${ }^{67}$ — which has greatly attenuated impacts on economic performance-but nary a word about file sharingwhich has decimated the sound recording industry and is threatening other content industries. ${ }^{68}$ The great difficulty of enforcing copyright protection in

63. See Stan J. Liebowitz, The Metric Is the Message: How Much of the Decline in Sound Recording Sales Is Due to File-Sharing? (Sept. 2011) (unpublished manuscript), available at http://papers.ssrn.com/sol3/papers.cfm?abstract_id=1932518.

64. See Matt Frisch, Digital Piracy Hits the e-Book Industry, CNN TECH (Jan. 1, 2010), http://articles.cnn.com/2010-01-01/tech/ebook.piracy_1_e-books-digital-piracy-publishingindustry (reporting that within 24 hours of release of Dan Brown's latest novel, The Lost Symbol, fans had "shared" more than 100,000 copies on Rapidshare, BitTorrent, and other file-sharing sites); see also Motoko Rich, Print Books Are Target of Pirates on the Web, N.Y. TIMES, May 12, 2009, at B1.

65. See Jeff Ulin, The Business of Media Distribution: Monetizing Film, TV AND Video CONTENT IN AN ONLINE WORLD (2009); see also SCOTT DONATON, MADison AND VINE: WHY THE ENTERTAINMENT AND ADVERTISING INDUSTRIES MUST CONVERGE TO SuRVIVE (2005).

66. See Epstein, Disintegration, supra note 2, at 503-07 (discussing UMG Recordings, 558 F. Supp. 2d 1055). The Ninth Circuit has since affirmed that decision. UMG Recordings, Inc. v. Augusto, 628 F.3d 1175 (9th Cir. 2011). Professor Epstein's critique of this decision is well-taken, but the issue is of small moment compared to the larger piracy problem plaguing content industries in the Internet Age.

67. See Epstein, Disintegration, supra note 2, at 483.

68. See Peter S. Menell, Infringement Conflation, 64 STAN. L. REV. (forthcoming 2012), available at http://papers.ssrn.com/sol3/papers.cfm?abstract_id=1949492 (noting the fallacy of scholars who are "far more troubled by the addition of 20 years to the end of the 
the digital age imposes direct costs on copyright owners and discourages investment in new projects. While it may provide a short-term windfall to those who "share" copyrighted works already in existence, rampant piracy dulls and distorts incentives to create, thereby reducing the quality of the flow of creative works.

The governance challenge in this area is two-fold. Society wants to encourage innovation in devices, platforms, and formats for dissemination of creative works, as well as provide strong incentives for the creation of such works. Until the digital revolution of the past decade, the technology and content industries functioned in a largely symbiotic manner. ${ }^{69}$ In general, previous new content perception and distribution technologies-such as phonographs, motion pictures, radio, television, cassette tapes, and videocassette recorders-generally expanded markets for content creators. These technologies supported stable business models for creators to appropriate a financial return on their investments. The technologies themselves discouraged unauthorized distribution of the content or embedded advertising in a manner that supported indirect appropriability. But the latest wave of technology-from peer-to-peer technology to digital video recorders that facilitate skipping of commercials - has undermined the inter-industry symbiosis of old. That has dramatically affected the efficacy (and sustainability) of the current model of copyright protection.

\section{COMPARATIVE INSTITUTIONAL ANALYSIS}

Society's problem is properly characterized as how best to govern resources, not how best to govern resources using private property (or more narrowly, how to apply a classical liberal notion of private property to all resources). In some cases, classical liberal private property might provide the best results. In others, property rights might need to be tailored to particular contexts. In others, public and non-proprietary governance regimes might better address the particular resource characteristics and social and technological dynamics. In many contexts, a mix of private and public

copyright term than the effective loss of rights during the first 20 seconds of a work's release").

69. See Peter S. Menell, Envisioning Copyright Law's Digital Future, 46 N.Y.L. SCH. L. REV. 63, 103-08 (2003). I do not mean to suggest that the content and technology industries have always gotten along. As one example, motion picture studios famously (and unsuccessfully) sued the maker of the first consumer videocassette recorder ("VCR") on grounds of contributory infringement. See Sony Corp. of Am. v. Universal City Studios, 464 U.S. 417 (1984). A decade later, VCR technology would fuel a massive market for video cassette tapes that greatly increased the ability of motion picture studios to appropriate returns on film productions. 
institutions will be best. As Professor Demsetz observed, advances in technology can affect the efficacy of private property in resource development and management. ${ }^{70}$ Just as barbed wire reduced the costs of marking and enforcing property rights_enabling the Western range to be governed through private property-software technology and the Internet have changed the balance for governing intellectual resources. Comparative institutional analysis provides the proper framework for determining the best means of governing these resources. ${ }^{71}$

Comparative institutional analysis recognizes that there are multiple ways to govern any resource and then evaluates which governance best accomplishes society's goals in light of the characteristics of the resource (e.g., the difficulty of capture, its use, its regenerative ability, and its interaction with other resources), the social conditions (the size of the relevant community, its cohesiveness, knowledge and values, political organization), technological conditions, and institutional infrastructures. ${ }^{72}$ This mode of analysis recognizes the inherent friction in real world institutions and hence takes a contextual, pragmatic, and empirical approach to the governance of resources. It recognizes that simplicity of idealized conceptions - such as the Coase Theorem or Professor Epstein's classical liberal cathedral—do not always function as hypothesized in real world conditions. Second best solutions often dominate idealized conceptions.

Professor Epstein contends that his classical liberal model of tangible private property has adapted to real world conditions over centuries of experience and thus is the appropriate foundation for governing intellectual resources. He is wrong on at least four counts. First, his model fails to account for the multi-faceted objective function of intellectual property policy. Second, he ignores many of the government policies that have augmented private property institutions. Third, he fails to deal with many of the key functional differences between tangible and intellectual resources. Fourth, his model lacks any empirical basis in the actual "current malaise" plaguing the intellectual property system. This Section sketches insights that comparative institutional analysis sheds on the governance of intellectual resources.

70. See Demsetz, supra note 31.

71. See DwYER \& MENELl, supra note 11; Komesar, supra note 11; Ostrom, GOVERNING THE COMMONS, supra note 11.

72. See Peter S. Menell \& John P. Dwyer, Reunifying Property, 46 ST. LouIS U. L.J. 599, 605 (2002). 


\section{Universality and Uniformity}

Professor Epstein's view that intellectual property protection should be universal-i.e., that all inventions meeting the novelty and non-obviousness requirements should be patentable and that all original works of authorship should be copyrightable-derives from an idealized model of private rights for tangible resources and optimism about transaction costs. ${ }^{73}$ In the real world, however, universality might not be the right policy for intellectual resources for numerous reasons: (1) the non-rivalrous nature of intellectual resources; (2) the importance of promoting cumulative innovation; (3) the availability of alternative appropriability mechanisms; (4) the challenges of determining which inventions merit protection - the patent quality problem; and (5) the notice problems associated with abstract forms of intellectual creativity. The one-size-fits-all approach works for tangible resources because most of these issues are not present.

Given the tremendous heterogeneity of fields of invention, it would be surprising if the same one-size-fits-all form of protection should govern all fields of inventions. ${ }^{74}$ There may be administrative reasons for universalitysuch as the difficulty of assigning inventions to particular regimes-but there would be potential benefits in calibrating protection to particular fields and possibly in excluding some fields for which the few incentive benefits, if any exist, are offset by substantial adverse effects and the presence of adequate non-patent means of appropriability. For example, with more than a decade of experience under the State Street Bank decision, the available evidence indicates that the social costs of business method patents are large in comparison to incentive benefits. ${ }^{75}$

Professor Epstein acknowledges that information differs from tangible resources in that it is non-rivalrous. ${ }^{76}$ There are many design elements for dealing with the non-rivalrous characteristic-from limiting duration, imposing use exceptions, and allowing for differential remedies and levy systems - but Professor Epstein sees but one: limit duration (although keep it uniform for all inventions and copyrighted works). Duration is an important tool, but it should not be the only one considered. Moreover, apart from a nod to fair use in copyright, Professor Epstein overlooks the cumulative innovation aspect of information. Most intellectual property

73. See Posner, supra note 32. See generally Ronald H. Coase, The Problem of Social Cost, 3 J.L. \& ECON. 1 (1960).

74. See Dan L. Burk \& Mark A. Lemley, Is Patent Law Technology-Specific?, 17 BERKELEY TECH. L.J. 1155 (2002).

75. See Brief of Menell \& Meurer, supra note 21, at 31-38.

76. See supra note 18. 
scholars consider cumulative innovation to be a critical rationale for limiting intellectual property rights in both time and strength of rights. Professor Epstein's twenty-year-from-filing duration limit for all technology is woefully arbitrary, as is the same term of protection for photographs, sound recordings, novels, and motion pictures. Any "first principles" account of intellectual property should grapple with that issue. Perhaps the answer lies in administrative costs and line-drawing problems, but it is a serious and complex inquiry.

\section{The Right To Exclude}

It is only after fundamental comparative institutional design choices are confronted that we get to the contours of intellectual property rights. Professor Epstein's article largely leapfrogs those issues to reach the right to exclude, which he characterizes as "the central component of any private property system." 77 Hence any slippage in this area poses the greatest threat to his classical liberal cathedral. Thus, Professor Epstein sees the Supreme Court's decision in eBay v. MercExchange ${ }^{78}$ as the critical battleground for pressing his carryover hypothesis.

The eBay case illustrates the principal symptoms of the malaise plaguing the patent system. Founded in late 1995, eBay proved the power of the Internet to reach large consumer audiences at relatively low cost. Within a short time, eBay established the most diverse marketplace bazaar in human history. ${ }^{79}$ Perhaps not surprisingly, various others recognized that the Internet opened up new opportunities for online commerce and online auctions in particular. Working independently and without significant investment, Thomas G. Woolston, an electrical engineer with a law degree, developed various concepts for online auctions for which he filed patent applications in April 1995. ${ }^{80}$ Such patents would not see the light of day until after they were granted. His first business venture based on these systems foundered. ${ }^{81}$ After his first patent issued in December 1998, he was able to raise $\$ 10$ million for MercExchange, an online travel venture. In addition to

77. See Epstein, Disintegration, supra note 2, at 486.

78. eBay Inc. v. MercExchange, L.L.C., 547 U.S. 388 (2006).

79. See Adam Cohen, The Perfect Store: Inside eBAy (2002); see also DanieL Nissanoff, Futureshop: How the New Auction Culture Will Revolutionize the Way We Buy, SELl, AND Get the Things We REALly WANT (2006).

80. See U.S. Patent No. 5,845,265 (filed Nov. 7, 1995) (“Consignment Nodes”); U.S. Patent No. 6,085,176 (filed Mar. 8, 1999) ("Method and Apparatus for Using Search Agents To Search Plurality of Markets for Items”); U.S. Patent No. 6,202,051 (filed Feb. 19, 1999) ("Facilitating Internet Commerce Through Internetworked Auctions").

81. See Ellen McCarthy, Waiting Out a Patent Fight with eBay, WASH. Post, Jan. 6, 2005, at E01. 
pursuing this business opportunity, MercExchange set out to enforce its patents. Its first lawsuit targeted GoTo.com, an online advertising company. In 2000, MercExchange's General Counsel met with an eBay representative and began discussion over MercExchange's patents. By the middle of that year, MercExchange's online travel business had collapsed and it focused its efforts on selling or licensing its patents to eBay. In 2001, MercExchange reached a $\$ 4$ million settlement agreement with GoTo.com. In September, it filed suit against eBay (and several related enterprises) in the Eastern District of Virginia asserting infringement of its three patents.

Judge Jerome Friedman dismissed most of the causes of action on summary judgment ${ }^{82}$ but allowed two infringement allegations-relating to a search feature and a "buy it now" feature (allowing consumers to buy some products on auction sites at a fixed price) - to proceed to trial. After a fiveweek trial, the jury ruled for MercExchange and awarded $\$ 35$ million in damages. ${ }^{83}$ Based upon his balancing of equitable factors, ${ }^{84}$ Judge Friedman declined to issue a permanent injunction, noting that MercExchange "did not practice its inventions and exists merely to license its patented technology to others" and the "growing concern over the issuance of business method patents." ${ }^{\prime \prime}$ In his view, general concerns about business method patents offset the public interest in maintaining the integrity of the patent system by favoring the patentee's interest in injunctive relief.

On appeal, the Federal Circuit invoked the property nature of patents in overturning the denial of the permanent injunction: "[b]ecause the 'right to exclude recognized in a patent is but the essence of the concept of property,' the general rule is that a permanent injunction will issue once infringement

82. See MercExchange, L.L.C. v. eBay, Inc. (MercExchange I), 275 F. Supp. 2d 695, 71115 (E.D. Va. 2003) (holding one patent invalid for inadequate written description and construing the other two patents not to implicate eBay's core auction technology), aff'd in part and rev'd in part, 401 F.3d 1323 (Fed. Cir. 2005), vacated, 547 U.S. 388 (2006).

83. In post-trial rulings, Judge Friedman reduced the damage award to $\$ 29.5$ million. See id. at 722 .

84. The MercExchange I court repeated the four-factor balancing test:

(i) whether the plaintiff would face irreparable injury if the injunction did not issue, (ii) whether the plaintiff has an adequate remedy at law, (iii) whether granting the injunction is in the public interest, and (iv) whether the balance of the hardships tips in the plaintiff's favor.

Id. at 711 (quoting Odetics, Inc. v. Storage Tech. Corp., 14 F. Supp. 2d 785, 794 (E.D.Va. 1998) (citing Weinberger v. Romero-Barcelo, 456 U.S. 305, 312 (1982)), aff'd, 185 F.3d 1259 (Fed. Cir. 1999)).

85. Id. at 713 . 
and validity have been adjudged." 86 The court limited departures from the general rule to circumstances in which " 'a patentee's failure to practice the patented invention frustrates an important public need for the invention,' such as the need to use an invention to protect public health." ${ }^{\prime 7}$ The Federal Circuit rejected the lower court's general concern regarding business method patents and specifically emphasized that injunctions should be "equally available to both" those who practice their patented inventions and those who do not. ${ }^{88}$ The Supreme Court granted certiorari. ${ }^{89}$

Professor Epstein's brief to the Supreme Court in support of MercExchange placed particular emphasis on the analogy between real and intellectual property in defending the Federal Circuit's general rule favoring the granting of permanent injunctions in patent cases. ${ }^{90}$ In particular, Professor Epstein urged that the Supreme Court follow the analysis and rule from Geragosian v. Union Realty Co., ${ }^{91}$ where the court required the removal and replacement of a drainpipe at a cost substantially exceeding the value of the encroached land.

The facts that the aggrieved owner suffers little or no damage from the trespass, that the wrongdoer acted in good faith and would be put to disproportionate expense by removal of the trespassing structures, and that neighborly conduct as well as business judgment would require acceptance of compensation in money for the land appropriated are ordinarily no reasons for denying an injunction. Rights in real property cannot ordinarily be taken from the owner at a valuation, except under the power of eminent domain. Only when there is some estoppel or laches on the part of the plaintiff or a refusal on his part to consent to acts necessary to the removal or abatement which he demands will an injunction ordinarily be refused. ${ }^{92}$

Even in the real property field, this case is considered an outlier and several jurisdictions have shifted away from the rigid bright-line rule to a "good faith improver" standard. ${ }^{93}$ Far more significantly, extrapolating from real property law to intellectual property law overlooks important distinctions between the

86. See MercExchange, L.L.C. v. eBay, Inc. (MercExchange II), 401 F.3d 1323, 1338 (quoting Richardson v. Suzuki Motor Co., 868 F.2d 1226, 1246-47 (Fed. Cir. 1989)).

87. See id. (quoting Rite-Hite Corp. v. Kelley, Inc., 56 F.3d 1538, 1547 (Fed. Cir. 1995)).

88. See id. at 1339.

89. See eBay Inc. v. MercExchange, L.L.C., 547 U.S. 388 (2006).

90. See Epstein eBay Brief, supra note 15.

91. 193 N.E. 726 (Mass. 1935).

92. See Epstein eBay Brief, supra note 15, at 16-17 (quoting Geragosian, 193 N.E. at 728 (citations omitted)).

93. See, e.g., Raab v. Casper, 51 Cal. App. 3d 866 (Ct. App. 1975). 
underlying resources at issue. Whether or not presumptions of irreparable harm are justified in the real property context, the instrumental nature of intellectual property rights demands thorough functional analysis.

Professor Epstein's functional analysis boils down to the ex ante benefits of having a rigid injunctive relief standard: it will encourage land developers to conduct due diligence, which will reduce the likelihood of disputes. ${ }^{94}$ Even in that context, this benefit must be balanced with notice problems and ex post inefficiencies. In the eBay case, as in many other patent disputes, the infringer could not have avoided the dispute through ex ante search because many patent applications are not publicly accessible. Furthermore, even if eBay had been able to find the MercExchange patents in the massive software patent haystack, the difficulties of determining the scope and assessing the validity of the patents would have imposed substantial costs and uncertainty.

The eBay case illustrates what comparative institutional analysis brings to the table. Professor Epstein acknowledges the notice problems inherent in the patent system- " $[t]$ he fuzzy boundaries inherent in the description of patent claims invite, of course, new entrants to game the system by coming as close to the original patent description without crossing the line." 95 But Professor Epstein ignores the opportunity to counteract these notice problems because he misapprehended their real world significance. ${ }^{96}$ His statement overlooks the fact that most patent cases-and particularly those in the software field-involve inadvertent infringement, not "gaming."," Applying a balancing test at the remedy stage can ameliorate the notice problems inherent in patent prosecution-as the applications in the eBay case were kept secret until issuance. ${ }^{98}$ The balancing test can also account for the

94. See Epstein, Disintegration, supra note 2, at 495.

95. See id. at 487.

96. See Menell \& Meurer, supra note 29.

97. See Christopher Cotropia \& Mark A. Lemley, Copying in Patent Law, 87 N.C. L. REV. 1421 (2009) (finding that only 10.9\% of complaints allege copying from the plaintiff's patent or the plaintiff's commercial product, and that most of those cases arise in the pharmaceutical and chemical fields; copying is alleged in less than 3\% of computer and software cases, and less than $1 \%$ involve proof of copying).

98. Later legislation provides that patent applications shall be published eighteen months after filing unless the applicant requests that the PTO not publish the application and the applicant has not filed an application for the same invention in a foreign jurisdiction that also requires publication. See 35 U.S.C. \122(b) (2006); District of Columbia Appropriations Act, 2000, Pub. L. No. 106-113, div. B, \1000(a)(9), 113 Stat. 1501, 1536 (1999) (incorporating into law the publication provisions contained in $\int 4502(\mathrm{a})$ of the American Inventors Protection Act of 1999, which are reprinted at 113 Stat. 1501A-561). This legislation partially addresses the notice problem but leaves a wide eighteen-month gap, which is possibly wider for applicants seeking protection only in the United States. 
problems of patent quality, the plethora of software and business method patents, the abstract and uncertain nature of patent boundaries, the difficulty of patent search, ${ }^{99}$ and the fuzziness and complexity of patent doctrines. ${ }^{100} \mathrm{It}$ is not feasible or economically desirable for firms to conduct thorough preclearance of many digital products or services. ${ }^{101}$ Hence, ex post balancing provides an important safety valve for the patent system.

A unanimous Supreme Court rejected the Federal Circuit's presumption that permanent injunctions should issue after findings of infringement in the absence of "extraordinary circumstances" and remanded the case for full consideration based upon the multi-factor equitable test. ${ }^{102}$ The concurring opinions largely repudiate the "intellectual property equals tangible property" proposition. ${ }^{103}$ Justice Kennedy, joined by Justices Stevens, Souter, and Breyer, emphasized the need to adapt the standards for injunctive relief to the evident changes taking place in the patent field. He suggests that courts should be more cautious in the granting of permanent injunctions under various circumstances arguably present in the eBay case: the use of patents by non-manufacturing entities to charge "exorbitant fees" and the vague and suspect validity of business method patents. ${ }^{104}$ Chief Justice Roberts, in an opinion joined by Justices Scalia and Ginsburg, leaned more toward

99. Unlike real estate, where property has defined boundaries on four sides, intellectual resources are multi-dimensional and hence can implicate dozens if not hundreds of patents.

100. Apparently, even Professor Epstein struggles with the details. He mistakes the means-plus-function provision of the written description, 35 U.S.C. $\int 112$, \ 6 - a statutory provision that interprets claims defined by reference to embodiments set forth in the patent's specification to include "equivalents thereof" as of the time of issuance-with the "doctrine of equivalents," which is a court-made rule that stretches claims as of the time of infringement to encompass devices that perform "substantially the function in substantially the same way to obtain the same result." See Graver Tank \& Mfg. Co. v. Linde Air Prods., 339 U.S. 605, 608 (1950); see also Warner-Jenkinson Co. v. Hilton Davis Chem. Co., 520 U.S. 17 (1997); Festo Corp. v. Shoketsu Kinzoku Kogyo Kabushiki Co., 535 U.S. 722 (2002). Confusion can sometimes arise as to whether means-plus-function claims are entitled to a second stretch under the doctrine of equivalents. The answer is yes with regard to technology that was not known in the art at the time that the patent issued. See Al-Site Corp. v. VSI Int'l, Inc., 174 F.3d 1308, 1320 (Fed. Cir. 1999).

101. Had eBay searched for MercExchange's patents in 1995, 1996, 1997, or much of 1998, it would have come up empty. Even if it had had access to these patents, its counsel could not have easily ascertained their boundaries or validity. Both the district and appellate courts struggled with those questions (and disagreed on several points).

102. See eBay Inc. v. MercExchange, L.L.C., 547 U.S. 388 (2005). On remand, the district court denied a permanent injunction based on balancing the equitable factors. MercExchange, L.L.C. v. eBay Inc. (MercExchange III), 500 F. Supp. 2d 556, 559 (E.D. Va. 2007).

103. 547 U.S. at 394-97.

104. See id. at 396, 397 (Kennedy, J., concurring). 
categorical rules, noting that the "long tradition" of granting permanent injunctive relief in the vast majority of patent cases in which infringement had been found reflected the "difficulty of protecting a right to exclude through monetary damages." 105 Chief Justice Roberts closed by calling for caution in departing from tradition, invoking Justice Holmes' oft-quoted observation that " 'a page of history is worth a volume of logic." "106 But the page to which he referred was not drawn from tangible property history, but rather intellectual property history. None of the Justices invoked the sanctity of property. Even Chief Justice Roberts focused on the problem of the adequacy of compensation, saying nothing of natural rights.

Professor Epstein did not react well to the Court's decision:

What is so hard to comprehend about this dismal performance is the utter lack of attention to the basic structure of an industry in which literally trillions of dollars depend on the sound operation of a patent system. The troll problem occupies a little corner of this vast universe, and yet the Court seems to be prepared to impose massive indecision and uncertainty on the entire system without ever stopping to think how it actually works. ${ }^{107}$

But the Court did consider how the universe works. As Justice Kennedy's concurrence in the eBay case expressly recognized, the "troll problem" is a serious concern in the software field, ${ }^{108}$ hardly a "little corner."

105. See id. at 395 (Roberts, C.J., concurring).

106. See id. (quoting N.Y. Trust Co. v. Eisner, 256 U.S. 345, 349 (1921)).

107. See Richard A. Epstein, Court Soft on Property Rights, FIN. TIMES (May 16, 2006), http://on.ft.com/AzHhBF.

108. 547 U.S. at 396-97; see also Allison et al., supra note 55; Terrence P. McMahon et al., Who Is a Troll? Not a Simple Answer, 7 SEDONA CONF. J. 159 (2006); Michael J. Meurer, Business Method Patents and Patent Floods, 8 WASH. U. J.L. \& POL'Y 309, 335-36 (2002); Michael J. Meurer, Controlling Opportunistic and Anti-competitive Intellectual Property Litigation, 44 B.C. L. REV. 509, 541 (2003). Professor Epstein's reaction may well reflect that his principal exposure to patent law has come through his ties to the pharmaceutical industry, for whom he has been (and may well continue to be) a paid consultant. See Richard A. Epstein, What's Good for Pharma Is Good for America, BosTON GLOBE, Dec. 3, 2006, at E1 (noting that Professor Epstein has "consulted for Pfizer"); Richard A. Epstein, Mad Scientists: Go Away, Ethics Police. Leave the NIH Alone, SLATE.COM (Feb. 15, 2005), http://slate.me/wLQilg; Carl Elliot, When Ethicists Have Conflicts of Interest, 52 DisSENT MAG., no. 4, Fall 2005, at 44, 44 ("What Epstein did not say (and what Slate did not reveal until later) is that Epstein has one of the same kinds of financial relationship to the pharmaceutical industry that he wants the $\mathrm{NIH}$ to preserve. Not only is Epstein a paid consultant to Pfizer, the world's largest pharmaceutical company, he also consults for PhRMA, the pharmaceutical trade organization."). PhRMA, the chief lobbying arm of the pharmaceutical industry, strongly advocated that the Supreme Court affirm the Federal Circuit's categorical approach to granting injunctive relief in patent cases. See Brief of Amicus Curiae Pharm. Research and 
Professor Epstein now attempts to spin the eBay decision and subsequent jurisprudence as essentially endorsing carryover of the tangible property paradigm to intellectual property: "[t]aken as a whole, the post-eBay decisions showed a decided, but by no means complete, tendency to revert back to class-based [by which he means, categorical or per se] rules." ${ }^{109}$ He refers to three such situations where injunctive relief is essentially automatic: where the patent owner "practices the patent," exclusively licenses the patent, or "warehouses the patented technology in order to make some substitute technology, patented or unpatented." the post-eBay cases reveals, the pattern is much more variegated. ${ }^{111}$ Although patent owners who compete in the market usually obtain permanent injunctions against infringers, courts have denied permanent injunctions following findings of patent infringement in cases involving competitors ${ }^{112}$ and granted injunctions in cases brought by non-competitors. ${ }^{113}$ Furthermore, the sheer number of cases denying injunctive relief in patent cases is astounding. Prior to the Supreme Court's eBay decision, one could count on one hand all patent cases denying injunctive relief following an infringement determination. The courts have declined to issue permanent injunctions in nearly $30 \%$ of cases (19 of 67 ) in the three years following the eBay decision. ${ }^{114}$

Professor Epstein also engages in some revisionist history in suggesting that his classical liberal framework recognizes a "disproportionate impact" exception within the "exceptional circumstances" to automatic injunctions under the now-rejected Federal Circuit test. ${ }^{115}$ He now suggests that it would be appropriate to deny injunctive relief where "the defendant has a complex

Mfg. of Am. in Support of Respondent, eBay Inc. v. MercExchange, L.L.C., 547 U.S. 388 (2006) (No. 05-130), 2006 WL 622122.

109. See Epstein, Disintegration, supra note 2, at 491.

110. Id. at 492.

111. See Ernest Grumbles, III et al., The Three Year Anniversary of eBay v. MercExchange: A Statistical Analysis of Permanent Injunctions, INTELl. PROP. TODAY (Nov. 2009), http://www.ip today.com/issues/2009/11/articles/three-year-anniversary-eBay-MercExchange.asp ("[T] here is no longer a general rule that a permanent injunction should enter after a determination of infringement. Instead, each case must be reviewed on its facts.”).

112. E.g., Telcordia Techs. Inc. v. Cisco Sys. Inc., 592 F. Supp. $2 d 727$ (D. Del. 2009) (finding no irreparable harm); Adv. Cardiovascular Sys. Inc., v. Medtronic Vascular, Inc., 579 F. Supp. 2d 554 (D. Del. 2008) (finding no irreparable harm, adequate remedy available at law, and public interest favors not granting injunction).

113. E.g., Commonwealth Scientific \& Indus. Research Org. v. Buffalo Tech. Inc., 492 F. Supp. 2d 600 (E.D. Tex. 2007) (finding patentee is a research organization); Novozymes A/S v. Genencor Int'l, Inc., 474 F. Supp. 2d 592 (D. Del. 2007) (finding patentee is a licensor).

114. See Grumbles, III et al., supra note 111.

115. See Epstein, Disintegration, supra note 2, at 491-92, 496. 
device with many elements, of which only one tiny component infringes the plaintiff's patent." 116 It should be noted that he made no such concession in his Supreme Court brief, which refers only to laches, equitable estoppel, and necessity (such as public health dangers) as exceptional categories for which injunctive relief might be withheld in patent cases. ${ }^{117}$ To the contrary, Professor Epstein specifically argued that "The Possibility of Patent Holdups Is Generally Not a Justification for Denying Injunctive Relief." 118 It was in this section that he invoked the encroachment analogy. There, he rejected the argument of fifty-two intellectual property law professors (including myself) that the injunctive relief balance should recognize the problems posed by "patentees who 'can obtain revenue in excess of the value of the technology by threatening to enjoin products that are predominantly no[n]infringing and in which the defendant has already made significant irreversible investments.' "119

Thus, Professor Epstein has revised his prior view of the classical liberal cathedral sub rosa to allow for another category of injunctive relief, although he still overlooks many of the critical functional distinctions between tangible and intellectual resources. Variegated rule structures and standards provide opportunities for separating equilibria within ostensibly uniform intellectual property systems. Thus, the $e$ Bay multi-factor framework can allow relatively strict injunctive relief for the pharmaceutical industry while providing more flexibility in the software field. Pharmaceutical companies typically practice their inventions, whereas many enterprises asserting software patents do not. Since $e B a y$, software trolls have fared poorly in their efforts to obtain injunctions, whereas practicing entities have done well. ${ }^{120}$

Other distinctive considerations might call for additional in-roads to the right to exclude in intellectual property law. For example, network externalities provide significant justification for promoting interoperability

116. Id. at 491-92.

117. See Epstein eBay Brief, supra note 15, at 8-12.

118. See id. at 14.

119. See id. (quoting Brief Amicus Curiae of 52 Intellectual Property Professors as Amici Curiae in Support of Petitioners at 6, eBay Inc. v. MercExchange, L.L.C., 547 U.S. 388 (2006) (No. 05-130), 2006 WL 1785363).

120. See Amgen, Inc. v. F. Hoffmann-La Roche, Ltd., 581 F. Supp. 2d 160, 210 (D. Mass. 2008) (noting, in granting injunctive relief to a pharmaceutical patentee, that " $[\mathrm{w}] \mathrm{hile}$ $e B a y$ has allowed courts to decline requests for injunctive relief where the plaintiff is a "patent troll,' eBay has changed little where a prevailing plaintiff seeks an injunction to keep an infringing competitor out of the market"); Andrei Iancu \& W. Joss Nichols, Balancing the Four Factors in Permanent Injunction Decisions: A Review of Post-eBay Case Law, 89 J. PAT. \& TRADEMARK OFF. SOC’Y 395 (2007). 
and limiting the exclusivity of software protocols and interfaces. ${ }^{121}$ Various policies that limit the right to exclude could address preservation and access in the digital age. ${ }^{122}$ The fair use doctrine and various compulsory licenses within the Copyright Act address the cumulative innovation problem. If copyright enforcement on the Internet proves ineffective, compulsory licensing might be needed as part of levy systems for digital content. The potential opportunities of such alternative governance strategies severely undermine the carryover hypothesis.

\section{Freedom of Contract}

Under Professor Epstein's classical liberal paradigm, property owners should have near-complete authority to license or sell property in whatever way they desire-with restrictions, with restrictions on further alienation, and without restrictions. From this vantage point, Professor Epstein takes aim at two limitations on freedom of contract in the intellectual property domain: (1) patent law's licensee estoppel doctrine-which prohibits contractual restrictions barring patent licensees from challenging the validity of a patent; ${ }^{123}$ and (2) the first sale doctrine in patent and copyright law-which bars post-sale restraints on patents or copyrights. ${ }^{124} \mathrm{He}$ would like to use the carryover hypothesis for this critique, but he faces an embarrassing problem: the law of tangible property restrains alienation in various contexts. ${ }^{125}$ Therefore he jettisons his "wisdom of the ages" justification for looking to tangible property doctrine in favor of just plain normative argument.

But if the normative version of the carryover hypothesis is to carry any weight, then we would expect Professor Epstein to build his analysis on the functional congruence of tangible and intellectual resources as regards freedom of contract. Yet he abandons that pretense as well. His analysis of licensee estoppel acknowledges that the Supreme Court's principal justification for licensee estoppel_- "the strong federal policy favoring free competition in ideas that do not merit patent protection" "126 in combination with the distinctive ability of patent licensees to police patent quality-has no

121. See Menell, supra note 37.

122. See Menell, supra note 25.

123. See Lear, Inc. v. Adkins, 395 U.S. 653, 676 (1969).

124. See 17 U.S.C. \109(a) (2006); Quanta Computer, Inc. v. LG Elecs., 553 U.S. 617 (2008).

125. See Epstein, Disintegration, supra note 2, at 498-99 (acknowledging "as a descriptive matter [that] the strongest objection to the carryover approach is often that it relies on subpar rules for land and chattels to set the framework for intellectual property rules").

126. See Lear, 395 U.S. at 656. 
analog in the domain of real estate leases. ${ }^{127}$ In criticizing the first sale doctrine, Professor Epstein overlooks the distinctive information and notice costs associated with intellectual resources. ${ }^{128}$

This is not to say that Professor Epstein's criticism of the licensee estoppel and first sale doctrine do not carry some force, ${ }^{129}$ but absolutely none of it derives from carrying tangible property doctrines or normative insights to governance of intellectual resources. The proper analysis should focus on the functional merits of intellectual resources.

\section{Takings and Intellectual Property}

Professor Epstein completes his article by exploring the extent to which the Takings Clause of the Fifth Amendment-requiring that private property not be taken without "due process"; limiting expropriations to "public use"; and requiring the payment of "just compensation" where justifiable takings occur-constrains government regulation of intellectual property rights. Grounded in his critique of Professor Radin's conceptual severance framework, Professor Epstein seeks to prevent the Supreme Court's Penn Central decision - which applied a balancing test to determine whether a land use restriction in a dense, interdependent urban setting constituted a taking ${ }^{130}$ — from spreading into the intellectual property domain. In Professor Epstein's view, partial takings should be compensable. ${ }^{131}$

127. See Epstein, Disintegration, supra note 2, at 501.

128. See Molly S. Van Houweling, Author Autonomy and Atomism in Copyright Law, 96 VA. L. REV. 549 (2010); Molly S. Van Houweling, The New Servitudes, 96 GEO. L.J. 885 (2008) (discussing the distinctive information and notice costs of information goods); Menell \& Meurer, supra note 29.

129. Professor Epstein does, however, make several mistakes along the way. For example, he places undue confidence on the reliability of patent examinations and the motivation of third parties to challenge patents.

130. Penn Cent. Transp. Co. v. City of New York, 438 U.S. 104, 124 (1978) ("In engaging in these essentially ad hoc, factual inquiries, the Court's decisions have identified several factors that have particular significance. The economic impact of the regulation on the claimant and, particularly, the extent to which the regulation has interfered with distinct investment-backed expectations are, of course, relevant considerations. So, too, is the character of the governmental action. A 'taking' may more readily be found when the interference with property can be characterized as a physical invasion by government than when interference arises from some public program adjusting the benefits and burdens of economic life to promote the common good.").

131. See Epstein, Disintegration, supra note 2, at 475-77 (citing RICHARD A. EPSTEIN, TAKings: Private Property AND THE POWER of EMINENT DOMAIN (1985); Richard A. Epstein, Supreme Neglect: How To Revive Constitutional Protection for PRIVATE PROPERTY (2008)). 
As a doctrinal matter, intellectual property receives treatment comparable to real and other forms of tangible property under the Takings Clause. ${ }^{132}$ The difficult question is to what extent the government will be able to regulate and reform intellectual property without triggering a taking. ${ }^{133}$ As with land use regulation-where the interdependency of resources, the pressures of population density and changing resource use, and the accretion of scientific knowledge about human impacts on ecosystems create the need for flexibility in government policies - there is a need to adapt intellectual property rights structures as technology and social conditions evolve. Professor Epstein opposes what he labels the "intellectual weakness" of ad hoc balancing tests ${ }^{134}$ but it may be his own intellectual rigidity that stands in the way of progress. He is correct to worry about the impact of flexibility in Takings jurisprudence on incentives to invest in research and development, but such concern loses sight of the larger societal objective. Poorly designed and obsolete intellectual property laws and policies undermine investment in research and development. For example, empirical evidence suggests that patent protection for "business methods" and even software may well deter software innovation. ${ }^{135}$

The optimal system for promoting traditional pharmaceutical innovation might not be appropriate for genomic research. Similarly, modest adjustments to copyright law to promote digitization of books could greatly promote access to orphan works, expand markets for books, and expand historical research. ${ }^{136}$ It remains to be seen whether Congress will achieve significant reforms in these areas and, if so, to what extent they would require "just compensation" to intellectual property owners who are adversely affected. But as courts venture into those untested waters, it is

132. See 35 U.S.C. $\int 261$ (2006) (stating that "subject to the provisions of [the Patent Act], patents shall have the attributes of personal property"); Ruckelshaus v. Monsanto Co., 467 U.S. 986 (1984) (holding that trade secrets in data relevant for regulatory approval were cognizable as property subject to the protections of the Takings Clause of the Fifth Amendment); Melville B. Nimmer \& David Nimmer, Nimmer on Copyright $₫ 1.11$ (2011) ("Constitutional Limitations on Retroactivity and 'Taking'") (observing that copyright protection cannot be contracted retroactively without raising due process and takings concerns); Adam Mossoff, Patents as Constitutional Private Property: The Historical Protection of Patents Under the Takings Clause, 87 B.U. L. REV. 689 (2007).

133. Although no court has yet addressed whether or how the Fifth Amendment's protections would be applied to retroactive changes in copyright law, Congress chose not to make the Computer Software Rental Amendments Act of 1990 retroactive so as to avoid depriving software owners of vested rights without compensation. See H.R. REP. No. 101735, at 10 (1990) (discussing the effective date of the Act).

134. See Epstein, Disintegration, supra note 2, at 474.

135. See BESSEN \& MEURER, supra note 35.

136. See Menell, supra note 25. 
important that they recognize that the interest in intellectual property is not liberty-based. It is instrumental: to promote technological innovation and artistic creativity. This suggests that balancing of interests will play some role.

\section{THE DISINTEGRATION OF INTELLECTUAL PROPERTY}

Professor Epstein's overarching thesis is that "any system of tangible and intangible property that hews to classical liberal conceptions runs no risk of collapse or disintegration." 137 As various points in his lengthy discourse, he vacillates among normative, positive, and jurisprudential assertions and criticisms. But by the end, Professor Epstein acknowledges as he must that modern decisions in patent and copyright cases "work to undermine the rights of exclusion and disposition so essential to the private law, and to undercut the protection of private property against government regulation." 138 That seems to address the positive and jurisprudential questions: intellectual property is disintegrating. In response to this, he comments, "[n]one of these developments are dictated by economic theory or modern social circumstances." "139 This statement is mistaken. Part III of this Article shows that there are strong functional forces pushing against Professor Epstein's thesis.

The rise of intellectual property in the information age highlights both the complexity and interdependence of resource development in modern technological societies. As indicated by the eBay litigation, efforts to shoehorn legal protection for such resources into the tangible property mold have failed and may well hasten the disintegration of the classical liberal conception of private property rights.

In patent law, the problems made manifest in accommodating digital technology within a unified patent system have led courts to take a much greater interest in limiting the scope of patentable subject matter, raising the non-obviousness hurdle, and substantially tempering the availability of injunctive relief. As explained above, there are strong functional justifications for these doctrinal developments. The emergence and growth of open source software and other open innovation platforms have shown that proprietary

137. See Epstein, Disintegration, supra note 2, at 522.

138. See id. at 523 .

139. See id. 
regimes are not always the best institution for promoting innovation under real world conditions. ${ }^{140}$

The full ramifications of these developments are far from clear. Limiting patentable subject matter to technological advances would reduce some of the problems plaguing several technology fields. Although the political opportunity for achieving systemic reform may be past, ${ }^{141}$ instituting a sui generis regime for software innovation may be the best course of action. Even Professor Landes and Judge Posner, who generally favor strong, exclusive private property rights in tangible resources, recognize that " 'depropertizing' intellectual property may sometimes be the soundest policy economically." ${ }^{\prime \prime 2}$

The challenges for private property protection in creative expression industries are more profound. Courts have substantially liberalized the fair use doctrine, ${ }^{143}$ which, in combination with the ease of digital distribution, is promoting a vibrant, symbiotic remix culture. Many traditional content companies are revamping their enforcement policies to encourage fan and collaborative creativity in light of technological, cultural, and enforcement conditions. Of far greater significance, peer-to-peer technology and other digital distribution platforms have resulted in rampant piracy of sound recordings and are threatening losses in other content markets. The record industry's enforcement campaigns have failed to staunch the hemorrhaging. Efforts to ramp up copyright enforcement have produced a pathological dynamic in which more aggressive enforcement increases anti-copyright sentiments and behaviors that might not be subject to effective deterrence through litigation. ${ }^{144}$ With the growing availability of darknets, online storage lockers, and other distribution technologies that are difficult to monitor, direct enforcement is becoming less feasible, raising the specter that the conventional copyright protection may lose its primacy in promoting creative expression in some important markets.

140. See Henry W. Chesborough, Open Innovation: The New Imperative for Creating AND Profiting from TeChNOlogy (2003); ERIC VON HipPel, Democratizing INNOVATION (2005); WEBER, supra note 11.

141. See Peter S. Menell, The Challenges of Reforming Intellectual Property Protection for Computer Software, 94 COLUM. L. REV. 2644 (1994).

142. See William M. Landes \& Richard A. Posner, The Economic Structure of INTELLECTUAL PROPERTY LAW 14 (2003).

143. See, e.g., Blanch v. Koons, 467 F.3d 244 (2d Cir. 2006); Bill Graham Archives v. Dorling Kindersley Ltd., 448 F.3d 605 (2d Cir. 2006). See generally Neil Weinstock Netanel, Making Sense of Fair Use, 15 LEWIS \& CLARK L. REV. 715 (2011) (showing that since 2005 the transformative use paradigm has come overwhelmingly to dominate fair use doctrine).

144. See Ben Depoorter et al., Copyright Backlash, 84 S. CAL. L. REV. 1251 (2011). 
Just as Professor Harold Demsetz predicted a shift toward private property institutions as the costs of internalizing externalities fall (due, for example, to advances in fence technology such as the invention of barbed wire) and the benefits of internalizing externalities rise, ${ }^{145}$ the opposite is also true. Increases in the costs of internalizing externalities-caused, for example, by the emergence of peer-to-peer technology enabling largely anonymous, unauthorized distribution of copyrighted works-push society away from private property institutions toward other forms of governance or anarchy. The record industry has shrunk by nearly half since the emergence of peer-to-peer technology. ${ }^{146}$

I suspect that Professor Epstein shares my concern about the loss of appropriability in the content industries. Where we diverge is in our openness to recognizing the cause of the problem and considering the full range of alternative policy solutions. Although I would like to believe that improving enforceability of copyright protection would reinforce the role of the market in compensating creators and providing a direct mechanism for valuing creativity, the growing enforcement challenges may require outside-of-thetangible-private-property-box solutions_-such as levy systems or other mechanisms for mimicking an idealized market solution. The rigidity of Professor Epstein's "classical liberal" perspective blinds him to these realities and preempts his consideration of alternative approaches to addressing the challenges of governing intellectual creativity in a dynamic technological and social world. The trade-offs are certainly complex, but they need to be confronted.

\section{CONCLUSIONS}

Rather than engage the rich body of comparative institutional and empirical scholarship illuminating the governance of intellectual resources, Professor Epstein has lashed himself to the mast of an obsolete and leaking ship. Professor Epstein's "structural unity" and carryover hypotheses go well beyond what sound philosophical reasoning, jurisprudential analysis, or empirical research can support. He seeks to impose a dogmatic strait-jacket on policymakers and judges. This is particularly dangerous at a time when new technologies are rapidly reshaping the landscape of technological innovation, expressive creativity, and the platforms for the dissemination of expressive creativity.

145. See Demsetz, supra note 31.

146. See Liebowitz, supra note 62. 
Promoting technological advance and intellectual creativity represents the greatest hope and challenge for our society and planet. It is essential that the framework for analyzing policy and legal options be broad and open-minded, not selective and dogmatic. The institution of private property that has developed for tangible resources provides valuable insights into how to encourage efficient economic development, but it is not a panacea for all resources, contexts, and societies. The conditions matter. Careful consideration of the characteristics of intellectual resources, comparative institutional analysis, and empirical research provide the keys to promoting innovation and creativity. 
